\title{
Дослідження характеристик телекомунікаційних систем використанням програмних реалізацій каналів зв'язку
}

Проведено дослідження характеристик телекомунікаційних систем та дана оцінка ефективності модуляції $i$ завадостійкого кодування з використанням програмних реалізацій математичних моделей каналів зв'язку на основі розроблених алгоритмів моделювання.

Ключові слова: канал зв'язку, математична модель, програмна реалізація, модуляція, завадостійке кодування, блокові коди.

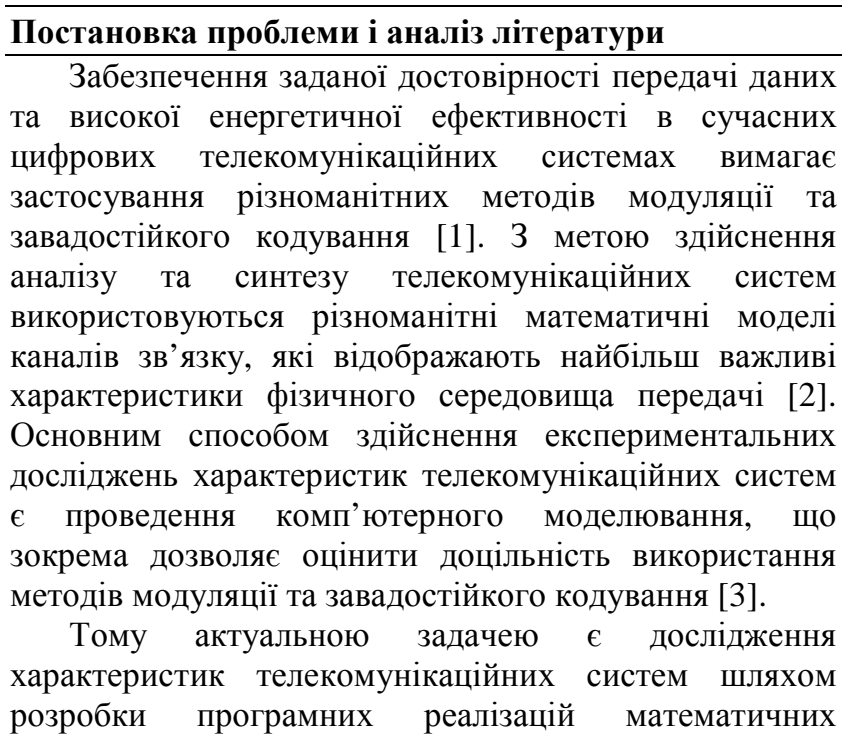

моделей каналів зв’язку 3 використанням спеціалізованого програмного забезпечення.

\section{Мета статті}

Розробка алгоритмів моделювання та програмних реалізацій каналів зв'язку у спеціалізованому програмному середовищі для дослідження характеристик телекомунікаційних систем.

\section{Основна частина}

В теперішній час існує безліч різних телекомунікаційних систем: волоконно-оптичні системи передачі, системи мобільного зв’язку, системи передачі даних тощо. Структурна схема телекомунікаційної системи в загальному вигляді [4], представлена на рис. 1.

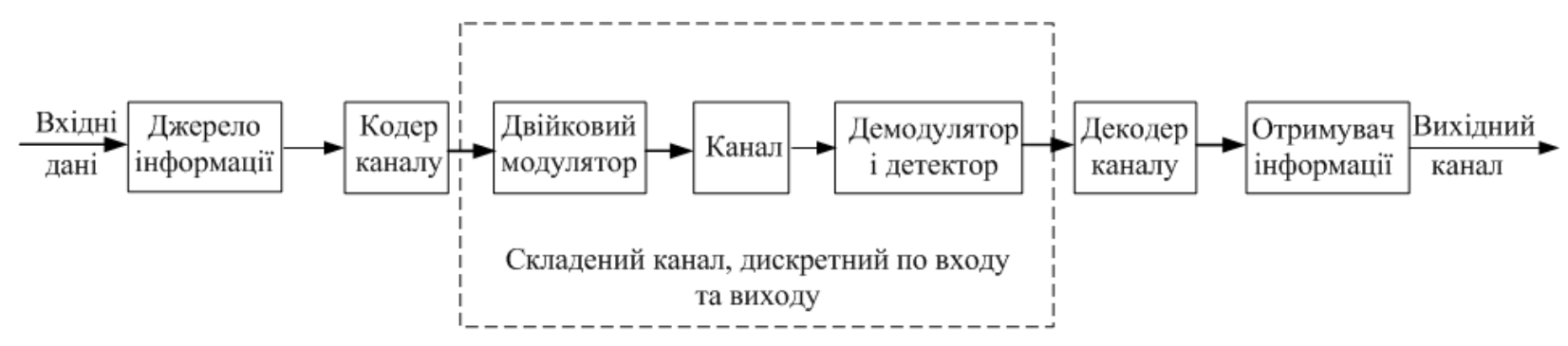

Рис. 1. Структурна схема цифрової телекомунікаційної системи

Основними елементами даної схеми є кодер/декодер каналу, модулятор/демодулятор, неперервний та дискретний канал зв'язку. Для оцінки якості кодування використовуються дискретні канали, а для оцінки ефективності як модуляції так і кодування - неперервні канали.

(C І.О. Асауленко, М.А. Штомпель, 2015
Найпростішим прикладом взаємодії двох дискретних джерел без пам'яті $\epsilon$ двійковий симетричний канал (ДСК) [2], що характеризується набором перехідних ймовірностей:

$$
\begin{aligned}
& P(Y=0 \mid X=1)=P(Y=1 \mid X=0)=p, \\
& P(Y=1 \mid X=1)=P(Y=0 \mid X=0)=1-p,
\end{aligned}
$$


де $X$ - символ, що передається;

$Y$ - символ, що приймається $з$ каналу;

$p$ - ймовірність помилкового прийому символу;

$1-p \quad-$ ймовірність правильного прийому символу.

Діаграма переходів ймовірностей помилок для ДСК представлена на рис. 2.

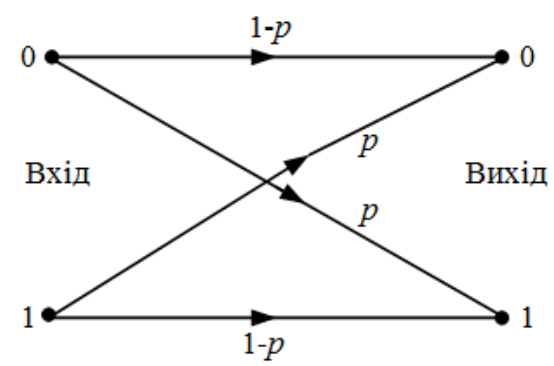

Рис. 2. Діаграма переходів ймовірностей помилок для ДСК

Важливою характеристикою каналу зв'язку $\epsilon$ пропускна здатність, що для ДСК визначається за формулою

$C=1+p \cdot \log _{2} p+(1-p) \cdot \log _{2}(1-p)$.

Для оцінки пропускної здатності та наглядного представлення розподілу ймовірностей помилок ДСК розроблено алгоритм моделювання даного каналу, що складається з таких етапів.

Крок 1. Формування двійкової інформаційної послідовності.

Крок 2. Формування каналу з заданою ймовірністю помилок.
Крок 3. Порівняння прийнятої послідовності 3 інформаційною.

Крок 4. Визначення коефіцієнта бітових помилок.

Крок 5. Побудова розподілу ймовірностей помилок.

Крок 6. Визначення пропускної здатності каналу.

$\mathrm{Ha}$ основі запропонованого алгоритму у спеціалізованому програмному середовищі створено програмну реалізацію ДСК, 3 використанням якої отримані результати моделювання для ймовірності помилки $p=0,2$ та для пропускної здатності, що наведені на рис. 3, 4 відповідно.

Із аналізу рис. 4 слідує, що при зростанні ймовірності помилки пропускна здатність даного каналу зменшується за нелінійним законом.

Розширенням ДСК є двійковий канал зі стиранням (ДСтК) [2], що відрізняється від попереднього появою третього додаткового символу, який з'являється у випадку, якщо не вдається достовірно впізнати прийнятий символ.

Набір перехідних ймовірностей для ДСтК описується виразами:

$P(Y=0 \mid X=0)=P(Y=1 \mid X=1)=0$,

$P(Y=x \mid X=0)=P(Y=x \mid X=1)=q$,

де $q$ - ймовірність стирання символу;

$x$ - символ стирання.

Для ДСтК пропускна здатність визначається наступним чином:

$C=1-q$

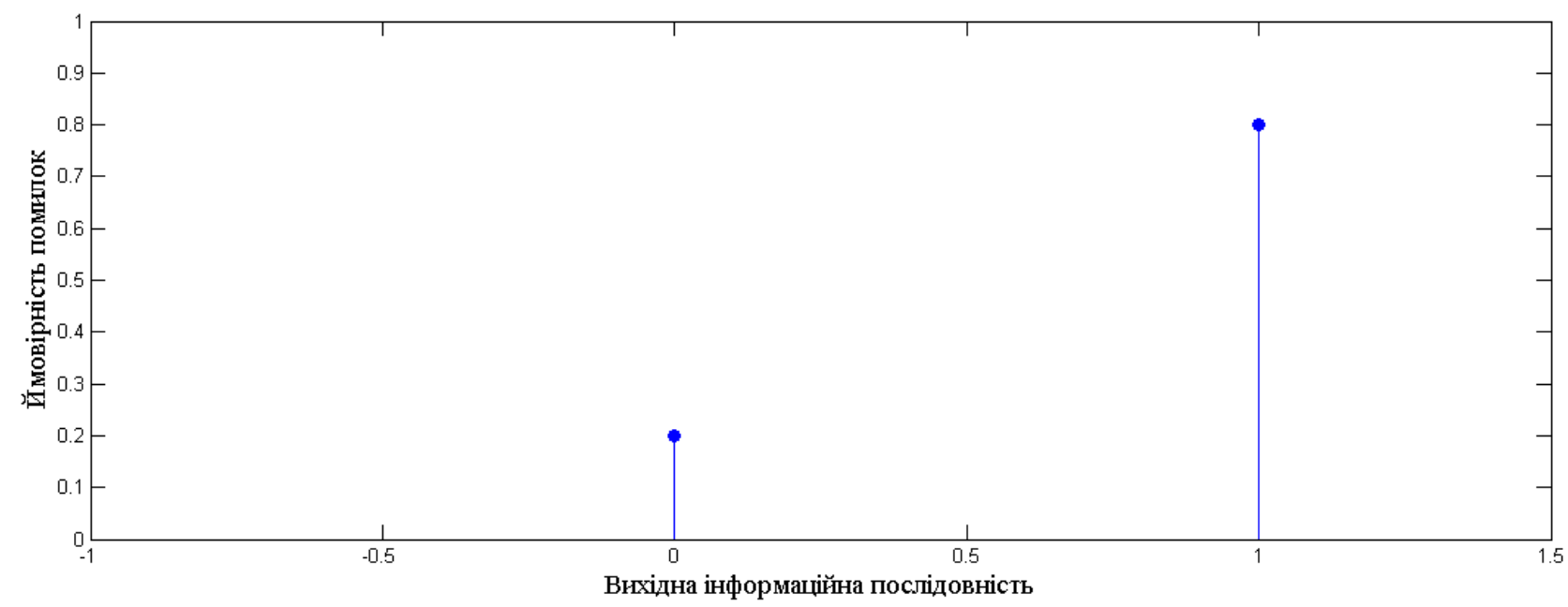

Рис. 3. Розподіл ймовірностей помилок для ДСК 


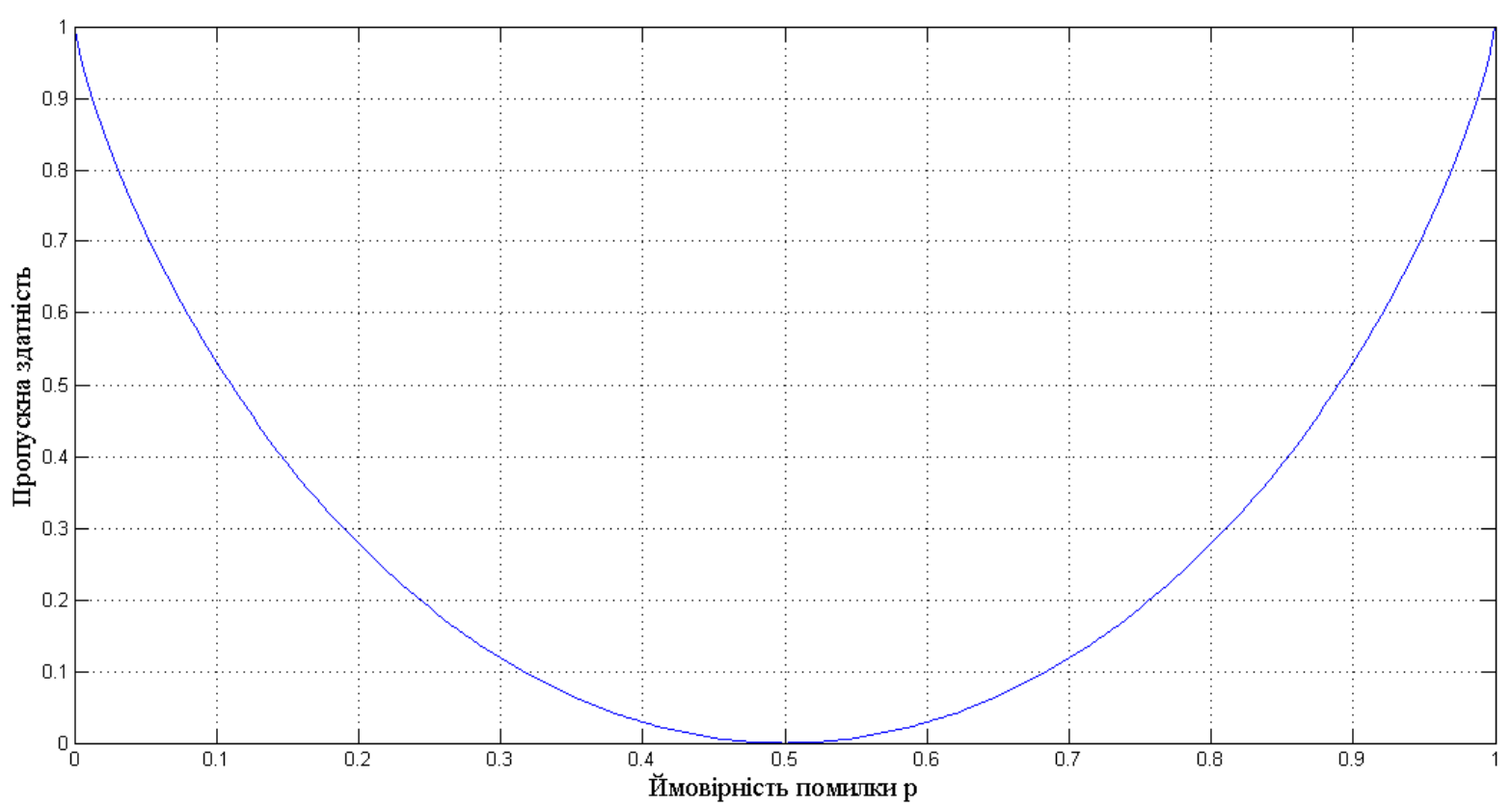

Рис. 4. Пропускна здатність ДСК

Для наочного представлення даного каналу на рис. 5 наведена діаграма переходів ймовірностей стирання.

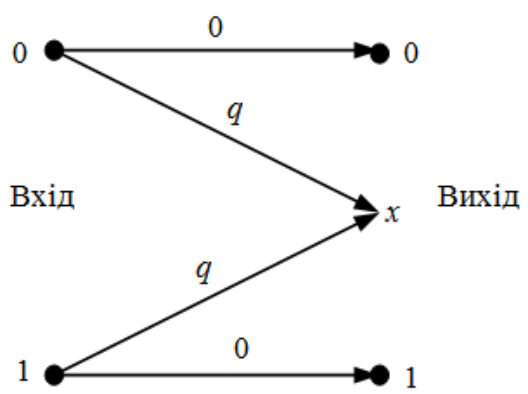

Рис. 5. Діаграма переходів ймовірностей стирання для ДСтК

Для оцінки основних характеристик ДСтК розроблено відповідний алгоритм моделювання, що складається з таких етапів.

Крок 1.Формування в вихідної інформаційної послідовності.

Крок 2. Формування каналу з заданою ймовірністю стирання.

Крок 3. Порівняння прийнятої послідовності 3 інформаційною.

Крок 4. Визначення коефіцієнта бітових помилок.

Крок 5. Побудова розподілу ймовірностей стирань.

Крок 6. Визначення пропускної здатності.
На рис. 6, 7 наведено результати моделювання, які отримані завдяки програмній реалізації, що створена на основі запропонованого алгоритму у спеціалізованому програмному середовищі.

I3 рис.7 випливає, що пропускна здатність ДСтК змінюється за лінійним законом та більша ніж для ДСК.

Найбільш широко застосовуваною моделлю неперервного каналу являється модель каналу 3 адитивним білим гауссовим шумом (АБГШ) [4], відповідно до якої переданий сигнал піддається впливу лише адитивного шумового процесу.

Канал з АБГШ характеризується рядом перехідних ймовірностей:

$$
p\left(y \mid X=x_{j}\right)=\frac{1}{\sqrt{2 \pi \sigma^{2}}} e^{\frac{-\left(y-x_{j}\right)^{2}}{2 \sigma^{2}}} j=0,1,
$$

де $\sigma$ - середньоквадратичне відхилення шумового процесу;

$$
x_{j}-\text { математичне очікування інформаційного }
$$
символу;

$y$ - вихідний символ. 


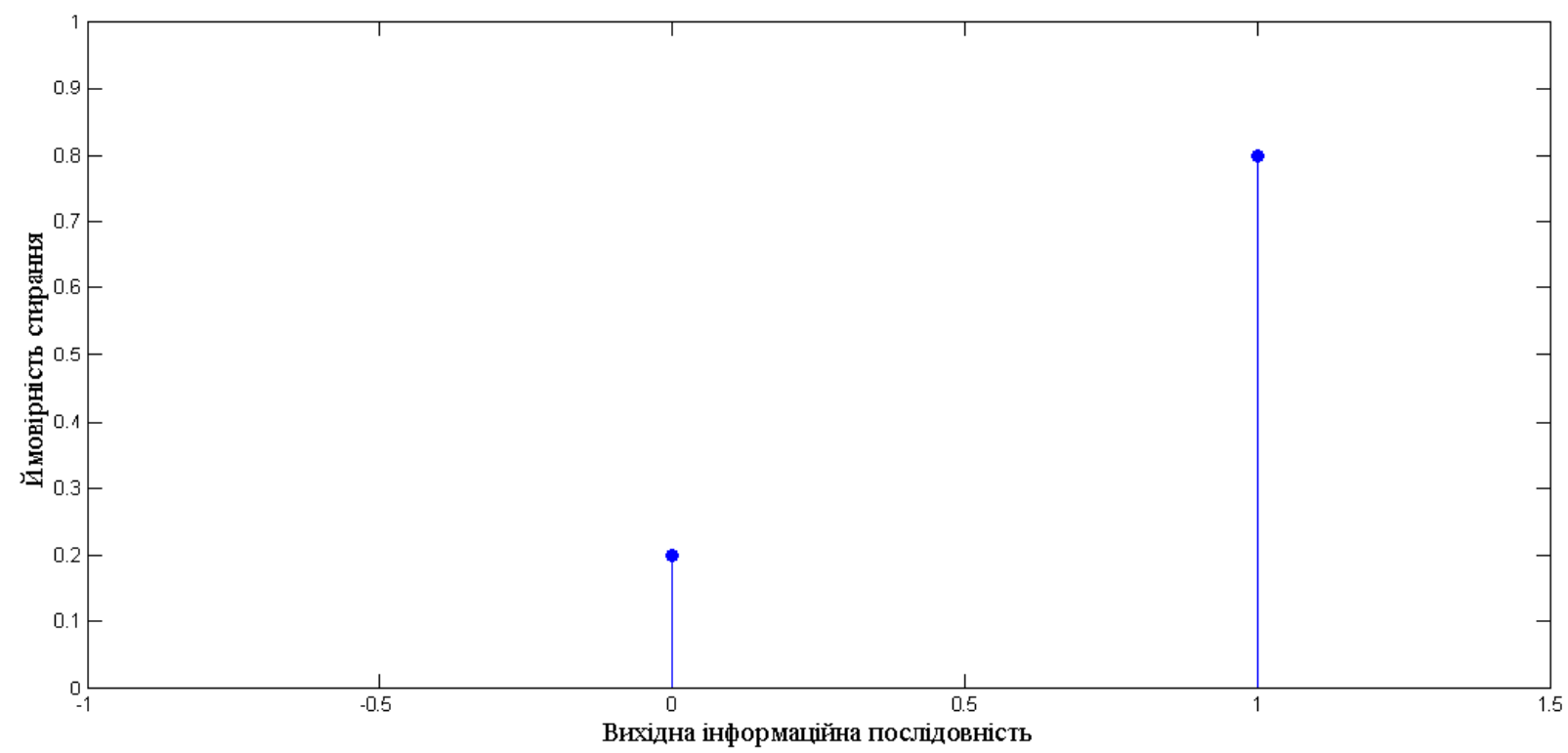

Рис. 6. Розподіл ймовірностей стирань для ДСтК

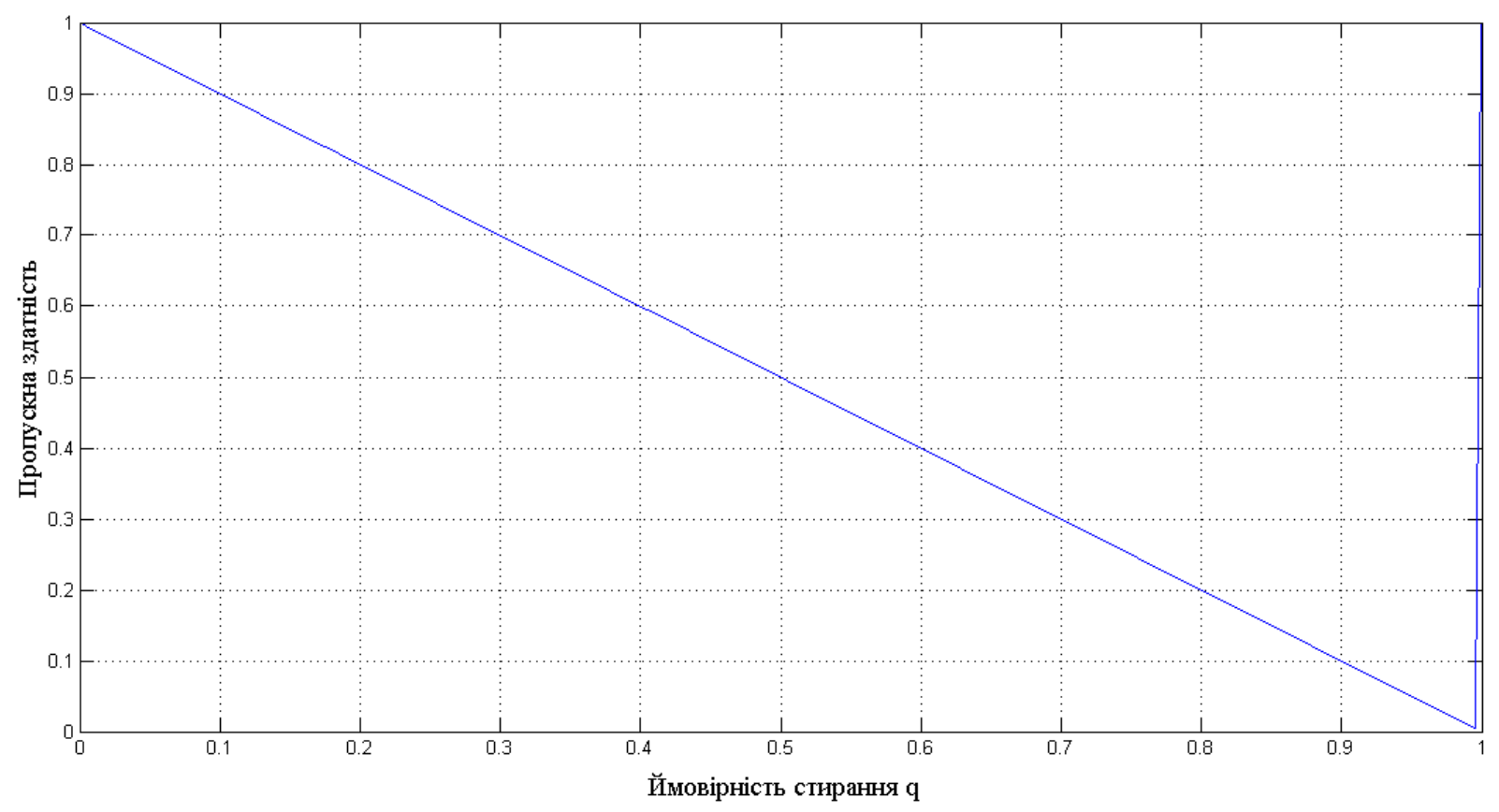

Рис. 7. Пропускна здатність ДСтК

Діаграму перехідних ймовірностей помилок для даного каналу подано на рис. 8 . 


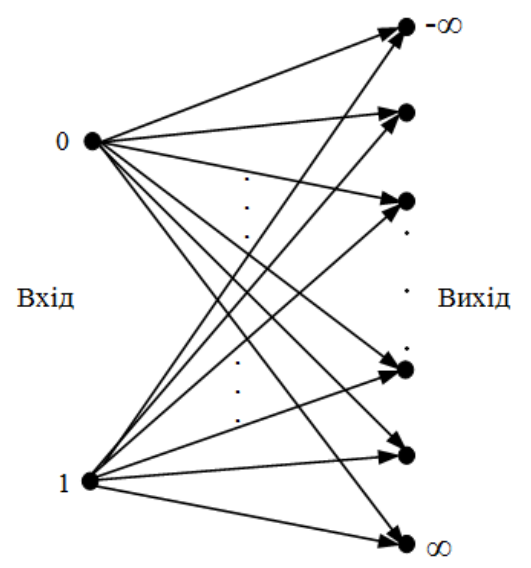

Рис. 8. Діаграма переходів помилок для каналу з АБГШ

Нормована пропускна здатність каналу з АБГШ визначається як

$\frac{C}{W}=\log _{2}\left(1+\frac{S}{N}\right)$, де $S$ - потужність сигналу, дБ;

$N$ - потужність шуму, дБ;

$W$ - ширина полоси пропускання, Гц.

Для оцінки властивостей каналу 3 АБГШ розроблено алгоритм моделювання, який містить наступні кроки.

Крок 1. Формування двійкової інформаційної послідовності.

Крок 2. Перетворення інформаційної послідовності у сигнал цифрової модуляції.

Крок 3. Формування сигналу 3 заданим відношенням сигнал/шум.

Крок 4. Формування інформаційної послідовності на виході демодулятора.

Крок 5. Визначення коефіцієнта бітових помилок.

Крок 6. Побудова розподілу щільності ймовірностей помилок.

Крок 7. Визначення пропускної здатності каналу.

У спеціалізованому програмному середовищі, на основі запропонованого алгоритму, створено програмну реалізацію каналу 3 АБГШ, 3 використанням якої отримані результати моделювання, що наведені на рис. 9, 10.

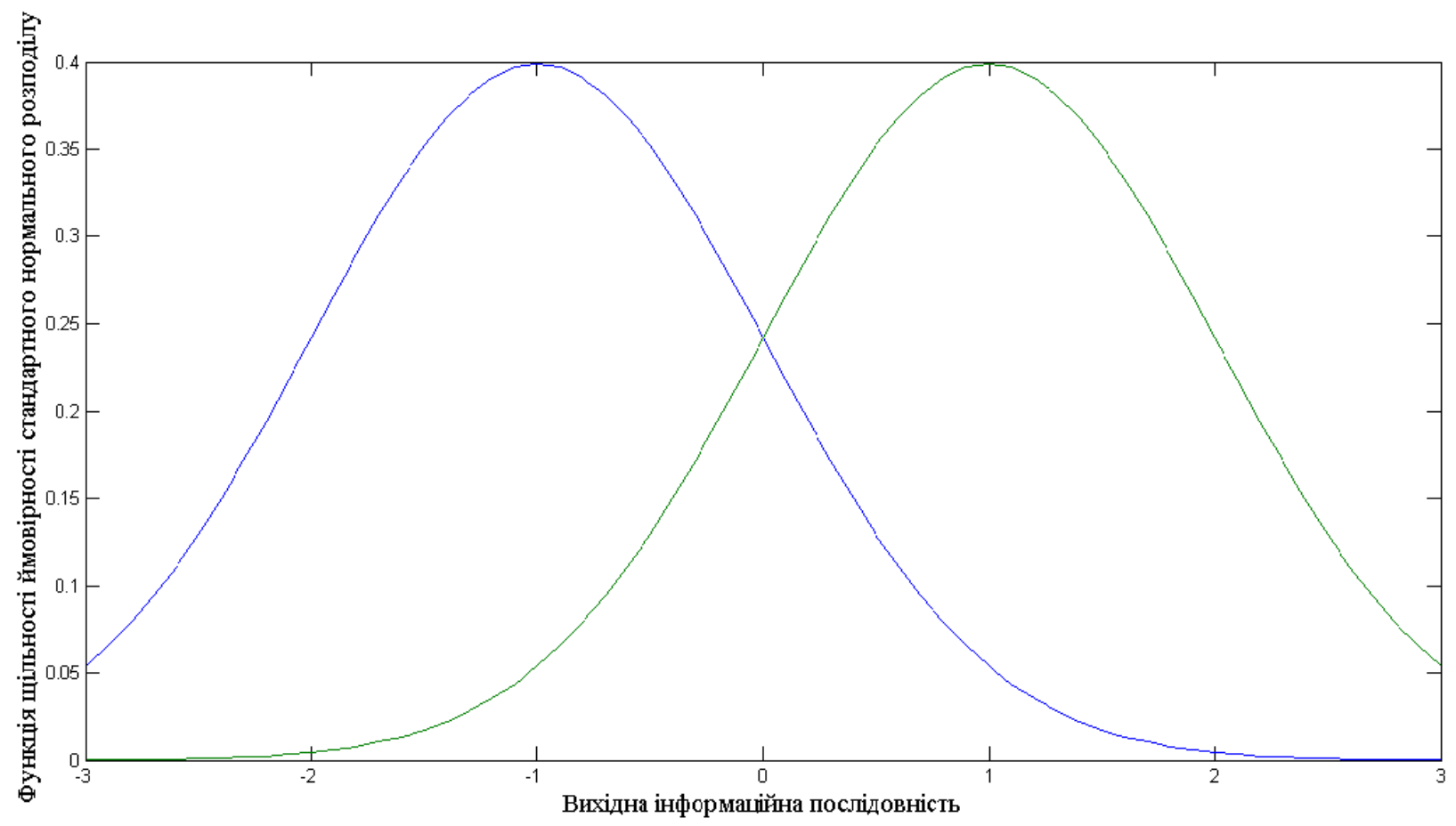

Рис. 9. Розподіл щільності ймовірностей помилок для каналу з АБГШ 


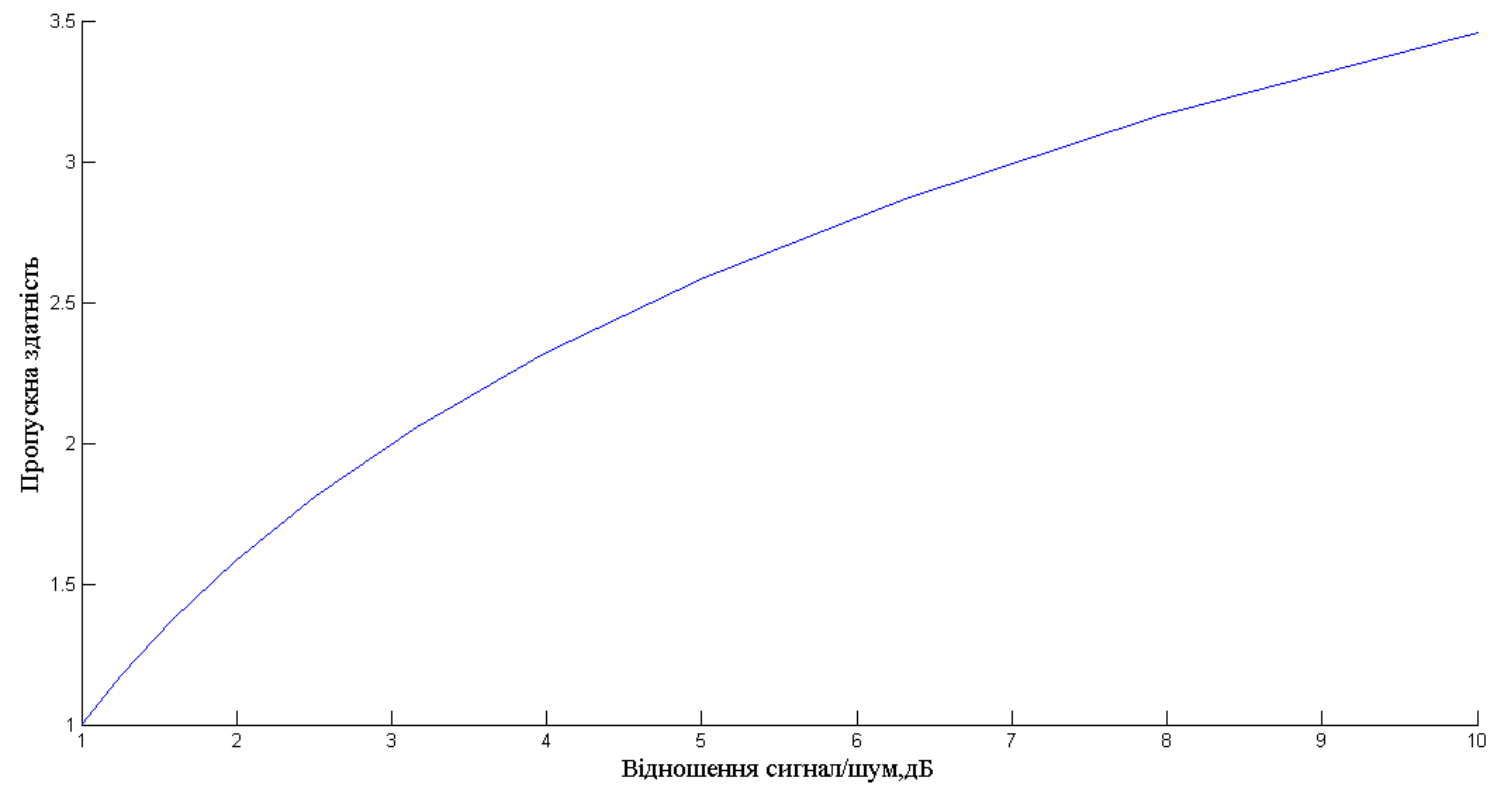

Рис. 10. Нормована пропускна здатність каналу з АБГШ

Із рис. 9 випливає, що розподіл щільності ймовірностей помилок для каналу з АБГШ дозволяє враховувати інформацію про надійність прийнятих символів. Із рис. 10 слідує, що пропускна здатність даного каналу більша ніж двох попередньо розглянутих.

3 метою оцінки ефективності модуляції в телекомунікаційній системі, в якості прикладу розроблено алгоритм моделювання двійкової фазової модуляції в каналі з АБГШ, що описується наступними кроками.

Крок 1. Встановити кількість символів вихідної інформаційної послідовності.

Крок 2. Зафіксувати діапазон відношення сигнал/шум.

Крок 3. Формування вихідної інформаційної послідовності.

Крок 4. Перетворення інформаційної послідовності у сигнал цифрової фазової модуляції.

Крок 5. Додавання АБГШ до модульованого сигналу.

Крок 6. Отримання дійсної частини прийнятого сигналу з АБГШ.

Крок 7. Формування інформаційної послідовності на виході демодулятора.

Крок 8. Визначення коефіцієнта бітових помилок.

Крок 9. Якщо досягнуто максимально допустимого значення відношення сигнал/шум, тоді виконати перехід до кроку 10, інакше виконати перехід до кроку 3.

Крок 10. Відображення залежності коефіцієнта бітових помилок від відношення сигнал/шум.
Крок 11. Встановлення діапазону сигнал/шум у логарифмичному форматі.

Крок 12. Перетворення відношення сигнал/шум у лінійний формат.

Крок 13. Обчислення теоретичного значення ймовірності помилок.

Крок 14. Відображення залежності теоретичного значення ймовірності помилок від відношення сигнал/шум.

Завдяки програмній реалізації розробленого алгоритму були отримани результати, що представлені на рис. 11. 


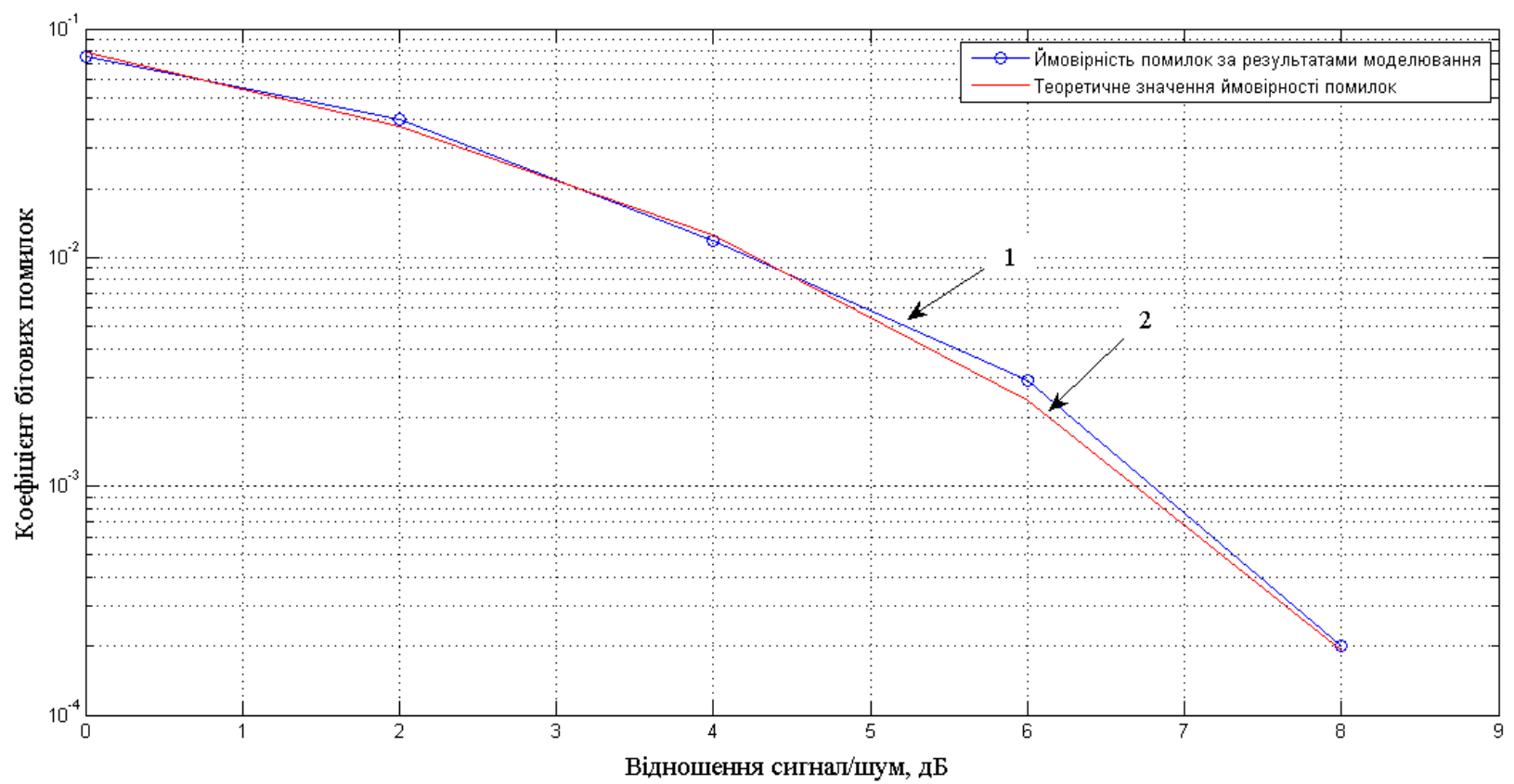

Рис. 11. Залежність коефіцієнта бітових помилок від відношення сигнал/шум:

1 - результати моделювання; 2 - теоретичне значення ймовірності помилок для двійкової фазової модуляції

Із рис. 11 слідує, що результати моделювання майже не відрізняються від теоретичних значень, а наприклад при коефіцієнті бітових помилок $10^{-4}$ вимагається відношення сигнал/шум близько 8 дБ.

Для підвищення енергетичної ефективності цифрової телекомунікаційної системи використовуються методи завадостійкого кодування, зокрема блокові коди.

Теоретичні границі для ймовірності помилок при двійковій фазовій модуляції, жорсткому та м'якому декодуванні блокового коду [5], визначаються за формулами:

$P_{b}=Q\left(\sqrt{2 \cdot \frac{E_{b}}{N_{0}}}\right)$

де $\frac{E_{b}}{N_{0}}-$ відношення сигнал/шум, дБ;

$P_{b} \leq \frac{1}{N} \sum_{m=t+1}^{N}(m+t)\left(\frac{N}{m}\right) p^{m}(1-p)^{N-m}$

де $N$ - довжина кодового слова;

$t$ - кількість помилок, котрі виправляє код;

$$
P_{b} \leq \frac{1}{2}\left(2^{K}-1\right) Q\left(\sqrt{2 \frac{E_{b}}{N_{0}} R_{c} d_{\min }}\right),
$$

де $R_{c}$ - швидкість коду;

$K$ - довжина інформаційної частини;

$d_{\text {min }}$ - мінімальна кодова відстань.

Результати розрахунків за формулами (1) - (3) для блокового $(7,4,3)$ коду наведено на рис. 12.

Із аналізу рис. 12 випливає, що наприклад при коефіцієнті бітових помилок рівному $10^{-4}$ відношення сигнал/шум для двійкової фазової модуляції становить близько 12 дБ, для жорсткого декодування становить дещо менше 12 дБ, а для м'якого декодування зменшилось майже на 2 дБ. Однак, в загальному випадку, м'яке декодування $є$ більш трудомістким та характеризується більшою складністю при практичній реалізації, ніж жорстке.

\section{Висновки}

Запропоновані програмні реалізації математичних моделей каналів зв'язку, що створені на основі розроблених алгоритмів у спеціалізованому програмному середовищі, дозволяють дослідити основні характеристики дискретних i неперервних каналів зв'язку та оцінити ефективність методів модуляції та завадостійкого кодування в сучасних цифрових телекомунікаційних системах. 


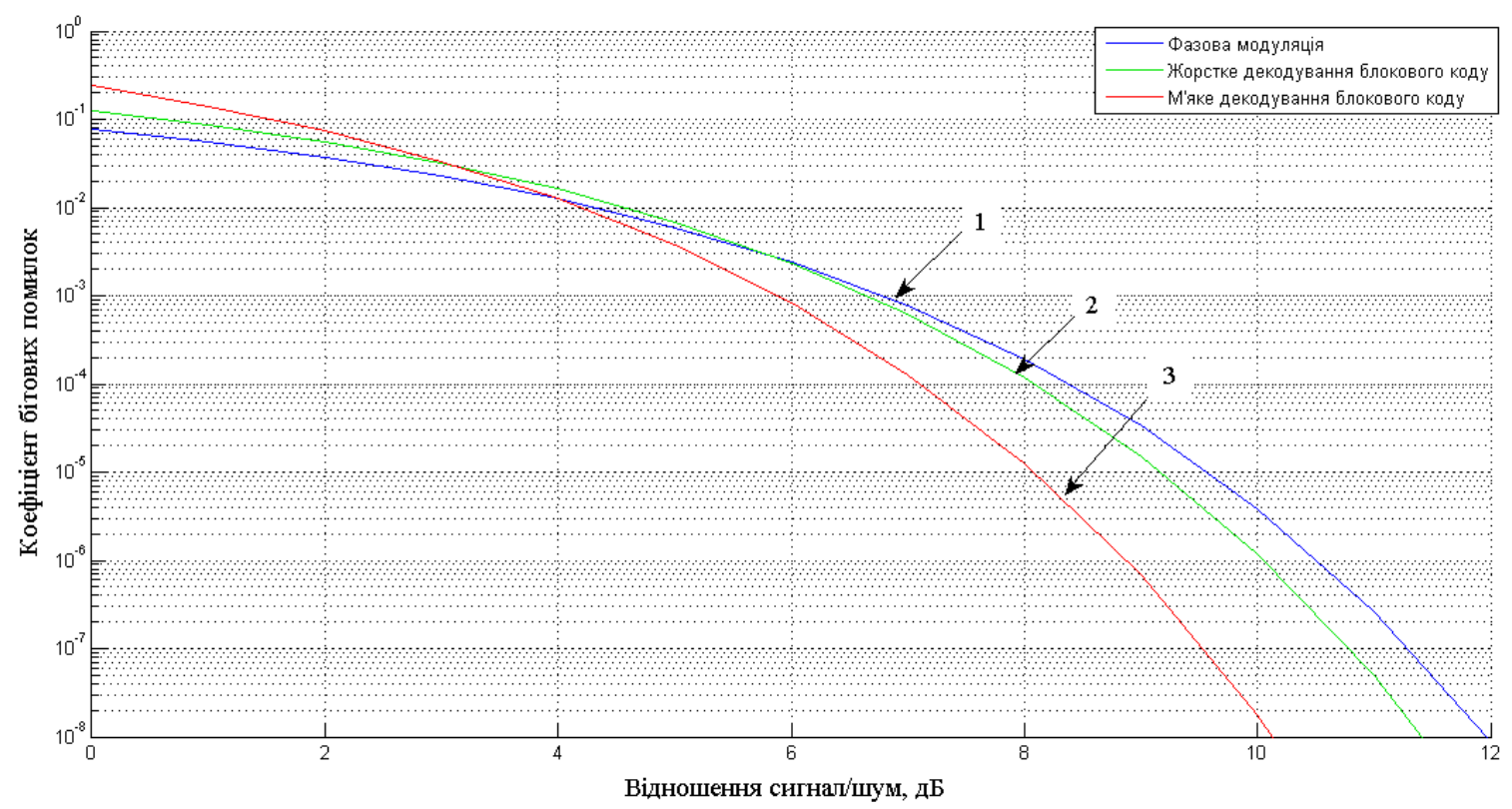

Рис. 12. Залежність ймовірності помилок від відношення сигнал/шум для двійкової фазової модуляції та блокового кодування: 1 - фазова модуляція,

2 - жорстке декодування блокового коду, 3 - м'яке декодування блокового коду

\section{Література}

1. Скляр, Б. Цифровая связь. Теоретические основы и практическое применение [Текст]: изд. 2-е, испр.: пер. с англ. - М.: издательский дом «Вильямс», 2003. - 1104 c.

2. Колесник, В.Д. Кодирование при передаче и хранении информации (Алгебраическая теория блоковых кодов). [Текст]: учеб. пособие для вузов / В.Д. Колесник. - М.: Высш. шк., 2009. - 550 с.

3. Васильев, К. К., Служивый М. Н. Математическое моделирование систем связи [Текст]: учебное пособие / К. К. Васильев, М.Н. Служивый. Ульяновск: УлГТУ, 2008. -170 с.

4. Золотарёв, В.В., Овечкин, Г.В. Помехоустойчивое кодирование. Методы и алгоритмы [Текст]: справочник / под. ред. чл. - кор. РАН Ю.Б. Зубарева. - М.: Горячая линия - Телеком, 2004. $126 \mathrm{c}$.

5. Прокис, Дж. Цифровая связь [Текст]: пер. с англ. / под ред. Д.Д. Кловского. - М.: Радио и связь, 2000. -800 c.

Асауленко И.А., Штомпель Н.А. Исследование характеристик телекоммуникационных систем с использованием программных реализаций каналов связи. Проведено исследование характеристик телекоммуникационных систем и дана оценка эффективности модуляции и помехоустойчивого кодирования с использованием программных реализаций математических моделей каналов связи на основании разработанных алгоритмов моделирования.

Ключевые слова: канал связи, математическая модель, программная реализация, модуляция, помехоустойчивое кодирование, блоковые коды.

Asaulenko I.A., Shtompel N.A. The investigation of the characteristics of telecommunication systems with the use of software implementations of communication channels. The investigation of the characteristics of telecommunication systems and the estimation of efficiency of modulation and antinoise coding using software implementations of mathematical models of communication channels on the basis of the developed modeling algorithms has been conducted.

Key words: communication channel, mathematical model, software implementation, modulation, antinoise coding, block codes.

Рецензент д.т.н., профессор Краснобаев В.А. (Полтавский национальный технический университет имени Ю.Кондратюка)

Поступила 22.12.20142. 